\title{
Commercialization of Scientific Activity at a Higher Technical School of East Ukraine in the Late 19th and Early 2oth Century
}

\author{
Maryna Gutnyk \\ Elena Tverytnykova \\ Volodymyr Sklyar \\ National Technical University \\ "Kharkiv Polytechnic Institute" \\ Kyrpychova 2, \\ Kharkiv 61002, Ukraine \\ E-mail:marinazoza@gmail.com \\ E-mail: tveekhpi@ukr.net \\ E-mail:sklyar_vm@ukr.net
}

\begin{abstract}
A study of the commercialization of the results of fundamental and applied researches by scientists in technical institutions of Ukraine was carried out. Based on the processing of archival materials, the activities of the representatives of the higher technical school in commercial projects, consulting and expert activities were studied, and the performance of this work was evaluated. On the example of the oldest technical institution of East Ukraine, the Kharkiv Practical Technological Institute (today the National Technical University "Kharkiv Polytechnic Institute"), it is demonstrated that attempts to implement the consulting and entrepreneurial sphere in a higher technical school in Ukraine were made already at the end of the 19th and the beginning of the 2oth century.

This institution of higher education had a unique character. Evidently, its exclusively "practical" approach to organizing the educational process outlined the strengthening of practical training of engineers and conducting in-depth research. Commercial activities were not widespread but became an integral part of the professional activity of the teaching staff.

The study showed that such business activities were not a common practice. The authors argue that the activities were carried out by a group of researchers who formed an informal professional institutional community, based on their own knowledge, experience, and global authority. V. Kirpichov and G. Latyshev effectively implemented commercial projects by order of the
\end{abstract}


railroad authorities. Successful entrepreneurial projects were implemented by the chemists M. Valyashko, O. Lidov, M. Zuev, the physicist O. Pogorelko, and the electrical engineers M. Klobukov, V. Kiyanica and P. Kopnyaev. Competitiveness of the inventions of these scientists was an important factor in the development of scientific and technological progress.

Keywords: commercialization of science, higher technical school, scientific research, technical consultations, Ukraine

At the current stage of the development of the higher technical education, the focus is on issues of implementing the latest approaches in the organization of the research activities of faculty members. Higher technical education is one of the main and most effective means of technologization of the society. The crises that have affected Ukrainian higher technical educational institutions have led to an urgent need to reform the educational system of engineers in accordance with the requirements and latest trends in developing economic potential. In addition, creating educational and scientific clusters as an innovative model for the development of new forms of cooperation between science, education and production is very urgent. The establishing of the clusters poses new challenges for the higher education institutions. The new system provides an opportunity to effectively use the accumulated knowledge, implement the results of fundamental and applied research, attract investments, and promote the competitiveness of a higher technical school. That is, the cluster should cover the full cycle of scientific production and commercialization of scientific products alongside with the creation of a special infrastructure on the basis of a higher education institution. The establishing of a successfully functioning cluster is an urgent problem for the modern higher education school of Ukraine. Countries such as the US, Germany, Japan, and Israel already have the experience of creating such systems of commercialization of research results, which gives them considerable advantage in the market of innovative products and technologies. The first attempts to implement the innovative and patent activity and the enterprise in the sphere of consulting were made by scientists of Ukrainian higher technical educational institutions in the late 19th century.

The study of the commercialization of academic science was carried out in the context of the modern history of science and technology. The conditions for research activities in higher educational institutions require new approaches to the implementation of scientific start-ups. 
The analysis of available publications showed that the history of commercialization of higher technical education at the end of the 19th and the beginning of the 20th century has not been the subject of special study of professional historians. This problem has been tackled by sociologists (Barnes, 1974; Ben-David, 1977; BenDavid \& Collins, 1966); in particular by Ben-David (1977), who is considered the founder of sociological research, and who has analyzed commercial projects in higher education school. However, these studies only analyzed the processes that took place in a higher education school in the 1960s and the processes at the beginning of the 20th century were excluded from their field of attention. The studies by economists on this subject (Clark, 1998; Ropke, 1998; Schulte, 1998; Altbach, 2011) generally relate to the period at the end of the 20th and the beginning of the 21 st century. Specialists in the commercialization of education, both from the United States (Coase, 1992; Tarrant, 1976; Hahn, 1976), and from European countries, e.g. Britain (Gray, 1931; Nevin, 2013), France (Blaug, 1986), and Austria (Schumpeter, 1908) only refer to individual facts of higher education in commercial matters. It should be noted that the concept of 'entrepreneurship' was introduced in the scientific work by Alexander Gray (1931, p. 300). Instead, the English scientist Richard Cantillon (Nevin, 2013) was one of the first to raise the problem of developing and forming an entrepreneurial university, giving to entrepreneurship a separate economic function and social risk function. In the works by such theorists as Joseph Schumpeter (1908), Friedrich August von Hayek (1945), and Bengt Karlof (1991) the role of innovation and innovative character of entrepreneurship (the use of new technologies, scientific developments, etc.) has been stressed. In his works, Jochen Röpke (1998) has noted the phenomenon of entrepreneurial university, innovation, academic knowledge and the development of a globalized economy.

The publication by Mercelis, Galvez-Behar and Guagnini (2017) is also useful. In this work, the authors, on the basis of examples from individual scientists and engineers, carried out a thorough analysis of the business activities of scientists in areas such as counseling, patent licensing and entrepreneurial activity. Attempts to commercialize the results of scientific applied research and developments are discussed in a publication (Tverytnykova, 2017), which shows that this process during the Soviet era was very slow, and the scientific potential of Ukrainian scientists remained almost unfulfilled.

According to researchers, the model of commercial university existed in Germany at the University of Berlin at the beginning of the 19th century, but at that time it was considered something negative that degraded the status of academic science. 
A clear strategy for the commercialization of scientific knowledge emerged only in the 1980s, at the end of the "industrial age". Formation of universitiescorporations took place primarily in the United States (Sevchenko, 2014, p. 3).

As to the situation of commercial activity in Sloboda, Ukraine, this issue has been fragmentarily investigated in the works of V. Onoprienko (1998a; 1998b) and in the monograph on the history of Kharkiv Technical Institute, or KhTI (Tverytnykova, Posvyatenko \& Melnik, 2015), and the current state of commercialization of the results of scientific works of universities and research institutions in the studies by Bogolib (2014) and Denysiuk (2006). However, these studies are single cases and not systematic.

Consequently, it follows from the above that in the late 19th and early 20th centuries the commencement of commercialization in the higher technical school of Ukraine has not been systematically investigated.

The aim of this article, which is based on scientific literature and the analysis of archival materials, is to study the experience of scientists from Ukrainian technical institutes in commercialization of the results of scientific activity in a historical retrospective, namely at the end of the 19th and the beginning of the 20th century in order to use this experience in modern conditions.

Today, the reform of higher education in Ukraine should take into account the peculiarities of the post-industrial dynamics in higher education institutions. Relying on the experience of predecessors, it is necessary to establish conditions for the creation of knowhow, the development of new technologies, and to learn how to effectively attract investors. Moreover, it is not only for economic benefits, but also goals of self-realization and spiritual and moral guidance.

Some facts about the participation of scientists of Ukrainian technical institutions in various scientific societies, commercial projects, consulting and expert events have been given in various publications, but no systematic study has been carried out. On the example of the oldest technical institution in Slobozhanshchina, we will try to analyze the start of entrepreneurship in higher education school at the end of the 19th and the beginning of the 20th century.

The development of industry of Sloboda Ukraine, or Slobozhanshchina, became especially fast after the reform of 1861. Railways, mines, transport, metallurgical and machine-building enterprises were rapidly developed, and new industrial districts were being built with centers in Kharkiv, Ekaterinoslav, Kyiv, Odessa, Yuzovka and Luhansk. Electrification of industrial enterprises and cities took 
place. Because of the growth in industrial production and the creation of large industrial enterprises, the energy economy began to develop in Ukraine.

As a result, a demand for specialists of different levels of qualification increased and the problem of creating an extensive system of higher technical education became topical. In Ukraine, the training of engineers for production took place in the classical universities of Kyiv, and Kharkiv, but this was not enough. Therefore, the need for an engineering personnel was decided to be satisfied through the establishing of a number of specialized higher technical education institutions.

The system of higher technical educational institutions started to be developed in Ukraine at the end of the 19th century. In order to improve the training of engineers for an industrial complex in 1885, the first higher technical institution, the Kharkiv Practical Technological Institute (KhPTI), was opened in the Slobozhanshchina area (Complete collection..., 1887). Studying the participation of private institutions in supporting scientific and technical research is still relevant. The priority position of the teaching staff in relation to consulting activities, primarily on scientific and technical problems, is due to the fact that in the late 19th and early 20th centuries, KhPTI was one of the three higher technical establishments in the territory of the then Slobozhanshchina. In addition to KhPTI, in this part of Ukraine operated the Kyiv Polytechnic Institute (since 1898) and Ekaterinoslav Mining School (since 1899). It should be noted that, given the unique position of the leading scientists of the KhPTI in the conditions of the deployment of the "industrial revolution", a large number of new enterprises appeared, and by the end of the 19th century, the city of Kharkiv had become a leading industrial center.

One of the features of KhPTI was its unique "practical" approach to organizing the educational process, which outlined the strengthening of the element of practicality in the training of engineers by mandatory seminars, laboratory and practical classes and industrial practices at enterprises. This induced the establishment of mechanical and chemical workshops in the institute's structure. At the department of chemistry, a soda factory, a glass oven, a ceramic workshop, a sugar refinery, a distillery, oil and soap plants, a leather processing workshop, and a gas plant were built. These small-sized manufactures performed the necessary work for the Institute, as well as served as training laboratories for future engineers.

The study of archival and other sources shows that alongside the research work, 
according to the mentioned programs, professors and teachers of KhPTI carried out research in laboratories and workshops upon the commission of entrepreneurs, provincial and city authorities, industrial enterprises and organizations, and zemstvos. To coordinate this work, a trustee council of local manufacturers and plant workers was created. The main responsibility of this council was to help in satisfying the needs of customers by improving the scientific and technical level of production. At the same time, there was the possibility of attracting funds from customers to strengthen the material and technical base of the institute (State Archives of the Kharkiv Region, F 770, op 1, n 246, p. 1).

Since its creation the KhPTI has had constant and mutually beneficial relations with industrial enterprises. First, these relations were in the city of Kharkiv and the Kharkiv Province. Such connections with the industry, which developed intensively in the East of Ukraine at that time, were extremely important as a means of expanding scientific and technological research and increasing its efficiency. Many professors of the Institute, considering the commercial value of their knowledge, were able to use their intellectual assets to commercialize their scientific and technical activities. They were primarily involved in consulting activity, part of which was scientific and expert work. Scientific and technical expertise was conducted in the interests of specific industrial enterprises and other institutions. All of this objectively contributed to the positive reputation of both concrete scientists and the KhPTI as a whole.

In the late 19th and early 20th centuries a key feature of KhPTI was the emergence of individual commercial projects. With the growth of the material and technical base and the improvement of the qualification level of the faculty, there was an increase in the number and quality of commercial projects. There were three research areas in the field of commercialization studies-mechanics, chemistry, and electricity.

At the end of the 19th century, especially effective researches were carried out in KhPTI on the orders of railway authorities. Thus, in October 1894, samples of high-grade iron and red copper for the construction of the Kursk-Kharkiv-Azov railway were investigated with the burst test in the mechanical laboratory of the institute. The results were sent to the customer. Investigations in the institute's mechanical workshop commissioned by the mining engineer Fon Dittmer of the Balashov railway to determine the properties of stones samples from 15 quarries and 7 types of bricks of various manufacturers were performed by professors V. Kirpichev and G. Latyshev. The results were sent to Fon Dittmer (State Archives of the Kharkiv Region, F 770, op 1, n 215, pp. 11, 14-15). 
According to archival documents, in subsequent years, the number of orders from factories and railroad authorities to be carried out in the institute's laboratories and workshops increased significantly. Thus, on the request of the chief of service of the Kursk-Kharkiv-Azov, Lozovaya-Sevastopol and Dzhankoy-Feodosia railways, water used for locomotives, taken from the Islam-Terek station, was studied and the physical properties of 78 samples of iron for boilers were tested (State Archives of the Kharkiv Region, F 770, op 1, n 259, pp. 1, 3, 18, 20, 40). The Southeast Railway Company turned to the director of the KhPTI to investigate the freezing and fragmentation of samples of stones, which was supposed to be used for the foundation and facing of the Elets-Valuisk railway's buildings and to analyze the mechanical properties of the ten samples of iron that should have been used for the same purpose. The results of the research were reported to the Society of Southeast Railways (State Archives of the Kharkiv Region, F 770, op 1, n 259, pp. 53-55, 66).

So, at the end of the 19th century, KhPTI became one of the leading scientific and technical institutions that directly carried out commercial research for rail transport. The results of these studies have objectively contributed to the improvement of rail transport activities on the one hand, and, on the other hand, the funds received from customers have contributed to the strengthening of the material and technical base and the increase in remuneration of the researchers of these studies in the faculty. An important feature of commercial activity was that the research was conducted mainly by single scientists, and in some cases professors involved their students in implementing these projects.

At the onset of World War I, the government of Russia wrote a letter to the director of the Kharkiv Technological Institute (which was the name of the KhPTI since 1898; Complete Collection..., 1901), in which he asked to help supply the army with medicines from abroad, the purchase of which was complicated. According to the proposal, the production of 12 items of drugs was to be organized in the institute's laboratories. The government guaranteed payment for the execution of such necessary work (State Archives of the Kharkiv Region, F 770, op 1, n 780 , p. 1). It is worth noting that pharmaceutical research was practically not carried out in KhTI at this time. However, Professor M. Valyashko later became the founder of the first higher pharmaceutical establishment in Ukraine in 1921 (Fesenko, 2012).

The studies of the leading chemists proved quite effective. The results of their work were commercialized. In 1916, Professor O. Lidov conducted chemical laboratory experiments to obtain carbon dioxide from natural limestone, carbon 
monoxide with nitrogen at normal temperature, and studied the processes of oxidation of coal by air at low temperatures in the presence of iron and other metals. Adjunct Professor M. Zuev carried out a study on defects and saturation in beet-sugar production. As a result of the active work of Professor M. Zuev and a laboratory assistant of the department of nutrition technologies, O. Shumilov, the first experimental sugar laboratory in the Russian Empire was founded in the higher technical educational institution. Here, professors and laboratory assistants carried out research work, and students conducted experimental and diploma works. The results of these studies were published in Proceedings of the Emperor Alexander III Kharkov Technological Institute and used in the educational process (Golova, 2014, pp. 70; 33). At a meeting with the KhTI's Director Professor P. Mukhachov, with the professors and heads of laboratories of the Institute it was decided to make a small amount of methanol, hexa-methylene, disinfectant soap and other preparations in the laboratory, if they would find funds and necessary equipment. As a result of research, the possibility to produce hygroscopic cotton wool in a cold method was discovered. The researchers identified a large amount of iodine from the water contained in the oil of the Baku oil industries (State Archives of the Kharkiv Region, F 770, op 1, n 780, pp. 16-17).

Investigations by mechanics and electricians of KhTI were of high level too. According to the projects by Professor K. Zworykin, many complex elements of steamboats, in particular a propeller, and technological equipment, including a cylindrical drilling machine, a blacksmith's forge for forging and welding of iron with the use of petroleum residues, etc. were constructed. Professor of the Institute, V. Knabbe developed a number of projects for the construction, equipping and reconstruction of industrial enterprises, in particular projects for the Kharkiv railway station. O. Pogorelko, who is famous in the scientific community as a theoretical physicist, assigned an important role to achievements in applied electrical engineering, especially for the development of the city's economy. Pogorelko was appointed as head of the commission on electricizing the city and headed the project of constructing a tram line in Kharkiv. Professor P. Kopnjaev of KhTI was responsible for the design of the tram line [Tverytnykova, Posvyatenko \& Melnik, 2015, pp. 27, 31, 51; 34; 82-87).

Professor Kopnjaev worked successfully as a technical expert at power plants, enterprises, where he consulted on practical issues of electrical engineering. $\mathrm{He}$ was involved as an expert on electrical equipment at the Provincial Hospital, a consultant on the consequences of the tram accident in Kremenchug, a consultant 
in the construction of a power plant in Kharkiv. In addition, during 1905-1907, Professor Kopnjaev developed the switching of tram substations in St. Petersburg and Lubenskaya substation in Moscow. In 1905, Kopnjaev was invited to work at Westinghouse Electric Company, which specialized in designing electric trams; in particular, the scientist participated in the development of the project of St. Petersburg Tram (Sklyar \& Tverytnykova, 2012, pp. 378-379).

In May 1917, with an aim to reactivate research, Professor V. Tyr made a proposition to the Educational Committee of KhTI to create a laboratory of mechanical technology using funds from the fulfilling of military orders in training workshops. The founder of the electrical laboratory, Professor M. Klobukov, carried out numerous scientific studies. For example, the scientist continued his experiments on the effects of alternating currents on electrolytes by applying them to a new method for determining coefficients. With the help of manufacturer A. Prostov, Klobukov implemented his scientific results in industry and received positive results (State Archives of the Kharkiv Region, F 770, op 1, n 180, p. 9).

Under the supervision of Kopnjaev, V. Kiyanytsia, an assistant at the laboratory of electrical engineering, carried out a study of the power of the electrical equipment of the Lugansk factory and the electrical equipment of the Nova Bavaria plant in Kharkiv. At the electrical laboratory, professors dealt with the verification and testing of measuring instruments for the Donbas, Kryvyi Rih, and Dnieper regions. At that time, it was the only laboratory that carried out applied metrology, which had both educational and extremely important scientific significance for the development of metrological support in Ukraine (Tverytnykova, 2010, p. 88).

However, next to the positive examples of the commercialization of scientific achievements in the KhTI, there were also projects that did not result in commercial success. An example of such unsuccessful commercialization is perhaps the activity of M. Pilchikov, the world-famous physicist, a talented researcher and experimenter, who worked in the KhTI on various issues of radio and radio control. In order to solve the problem of wireless telegraph, the scientist was looking for new ways to use the radio. He made a comparative analysis of methods for transmitting signals at a distance and identified the most successful of them, constructed a number of new devices, such as the radio and digital signals receiver. Also, he constructed a new relay, which was innovative at that time. In the electrotechnical laboratory, he produced a model of a new protection for battleships and cruisers. The scientist repeatedly traveled to France and Germany, where he studied new discoveries in 
the field of radio communications. In subsequent years, he continued to observe spectral polarization, ionization, and electrical conductivity of the atmosphere. But these innovations were not developed commercially. Pilchikov built a special telegraphic stationary station at the KhTI's meteorological observatory and a moving station in the car, and also purchased a number of new devices for physical and electrical laboratories, all at his own expense (State Archives of Kharkiv Region, F P-1682, op 1, n 516, pp. 29-32).

It should also be added that the activity by S. Timoshenko contributed significantly to the development of applied technical sciences in Ukraine. The scientist emphasized that the experimental base of technical sciences is the basis for effective realization of the achievements in the production and proposed a program of institutionalization of applied sciences, the creation of a network of research centers that contributed to the revitalization of scientific research in subsequent years (Onoprienko, 1998a, pp. 7-8).

Calculations carried out on the basis of archival documents and reports published in the Proceedings of Emperor Alexander III Kharkov Technological Institute and Proceedings of the South Russian Society of Technologists during the period 18941917 show that more than 300 researches were carried out in the laboratories of KhTI on the commission of enterprises, transport organizations, individual owners, and zemstvos. But the total number of researches should be higher, because the results of these studies do not cover the initial period of the existence of KhPTI (1885-1893). It is also necessary to take into account the effectiveness, because the number of professors in the first years of Institute's operation did not exceed 12.

Despite the fact that these "events" took place more than 100 years ago, the experience in commercial activities gained at that time is quite relevant for today's Ukraine, where, unfortunately, there is no systematic cooperation between financial and industrial groups and the higher technical school.

However, one should not overestimate the scale and results of the commercial activity of scientists of the higher technical school, in particular the KhTI. At the end of the 19th and the beginning of the 20th centuries there was a significant technological gap between the Russian Empire (which at the time included Slobozhanshchina) and the leading Western European countries and the United States. Therefore, it is very important to identify the materials on the emergence of commercialization of science in Ukraine's higher technical school during the period. 
Unfortunately, in modern literature devoted to the history of higher technical schools of Ukraine in general, and the KhTI in particular, the problems of commercialization of science have been presented only fragmentarily. The continuing of research on commercialization in the higher technical schools of Ukraine is rather promising. This will enable us to determine a more complete picture of this important aspect of the history of science and technology in the late 19th and early 20th centuries.

As the historical experience of KhPTI testifies, the commercialization of scientific research began already in the late 19th and early 20th century. These studies were applied in production. However, in today's Ukraine, there is no evidence of enterprises investing in the strengthening of the material and technical base of a higher education institution. So, as experience shows, commercialization is beneficial not only to higher technical schools but also to industrial enterprises.

\section{References}

Altbach, P. G. (2011), 'The past, present, and future of the research university,' in P. G. Altbach \& J. Salmi (eds.) The Road to Academic Excellence: The Making of WorldClass Research Universities, Washington, DC: The World Bank, pp. 11-32. https://doi.org/10.1596/9780821388051_CH01

Barnes, B. (1974), Scientific Knowledge and Sociological Theory, London: Routledge.

Ben-David, J. (1977), Centers of Learning: Britain, France, Germany, United States, New York: McGraw-Hill. https://doi.org/10.2307/2090769

Ben-David, J. \& Collins, R. (1966), 'Social factors in the origin of a new science: the case of psychology,' American Sociological Review, vol. 31, no. 4, pp. 451-465.

Blaug, M. (1988), 'Say, Jean Baptiste,' in Great Economists before Keynes: An Introduction to the Lives \& Works of One Hundred Great Economists of the Past, Cambridge: Cambridge University Press, pp. 211-212.

Bogolib, T. M. (2014), 'Kommertsializatsiia nauchnykh razrabotok universitetov,' Upravlenie ekonomikoi: teoriia i praktika, no. (618), pp. 33-50.

Chernysh (née Shulga), I. M. (2008), 'Historical-biographical analysis of the activities of the first teachers of the chemical department of the Kharkiv practical technological institute,' Retrieved from http://inb.dnsgb.com.ua/2008-1/08cimpti.pdf [accessed Oct 2019]

Clark, B. R. (1998), Creating Entrepreneurial Universities: Organizational Pathways of Transormation, London \& New York: International Association of Universities Press and Pergamon-Elsevier Science. 
Coase, R. (1992), 'The institutional structure of production,' The American Economic Review, vol. 82, no. 4, pp. 713-719.

Complete collection... (1887), 'Complete collection of laws of the Russian Empire. Collection 1881-1913: vol. 5 (1885),' St. Petersburg, pp. 156-163.

Complete collection... (1901), 'Complete collection of laws of the Russian Empire. Collection 1881-1913: vol. 18 (1898),' St. Petersburg, pp. 525-532.

Denysiuk, V. A. (2006), 'Kommertsializatsiia rezul'tatov nauchno-issledovatel'skikh rabot: problemy i perspektivy,' Vestn. NAN Ukrainy, no. 5, pp. 39-53.

Fesenko, V. Yu. (2012), 'Mykola Valiashko - stanovlennia naukovtsia' [Mykola Valyashko - Founder of domestic pharmaceutical education], Gileya, no. 66, pp. 92-98.

Golova, V. V. (2014), 'Scientific achievements of Professor A. P. Lidov in the field of the gas business in the late XIX - early XX centuries,' Bulletin of NTU "KPI". Series: History of Science and Technology, vol. 30, no. 1073, pp. 69-76.

Gray, A. (1931), The Development of Economic Doctrine: An Introductory Survey, London \& New York, Longmans, Green \& Co.

Hahn, R. (2013), 'Ronald Harry Coase (1910-2013): Nobel-prize winning economist whose work inspired cap-and-trade,' Nature, vol. 502, no. 449. https://doi.org/10.1038/502449a

Hayek, F. A. (1945), 'The use of knowledge in society', American Economic Review, vol. 35, no. 4, pp. 519-530.

Karlof, B. (1991), Business Strategy: [Concept. Content. Symbols], Transl. from English, Moscow: Economics.

Mercelis, J.; Galvez-Behar, G. \& Guagnini, A. (2017), 'Commercializing science: nineteenth- and twentieth-century academic scientists as consultants, patentees, and entrepreneurs,' History \& Technology, vol. 33, no. 1, pp. 4-22. https://doi.org/10.1080/07341512.2017.1342308

Nevin, S. (2013), 'Richard Cantillon: the father of economics,' History Ireland, vol. 21, no. 2, pp. 20-23.

Onoprienko, V. I. (1998a), Fundamentalization of Scientific Search in Technical Sciences: The 70th Anniversary of the Academy of Sciences of the Ukrainian SSR, Kyiv: Znanie.

Onoprienko, V. I. (1998b), History of Ukrainian science XIX-XX centuries. Tutorial, Kyiv: Lybid.

Radoguz, S.; Gutnyk, M. \& Zaitsev, R. (2018), 'The contribution of Kharkiv Practical Technological Institute scientists to electrification of Kharkiv City at the end of XIX - the beginning of XX century,' in Proceedings of the 2018 IEEE Ukraine Student, Young Professional and Women in Engineering Congress (UKRSYW), October 2-6, 2018, Kyiv, Ukraine, pp. 82-87.

Röpke, J. (1998), The Entrepreneurial University: Innovation, Academic Knowledge Creation and Regional Development in a Globalized Economy. Retrieved from https:// pdfs.semanticscholar.org/a492/feccb37145329f4c0ce25a671de2f51c1a04.pdf?_ 
$\mathrm{ga}=2.150750902 .1202928765 .1570183844-1166137819.1570183844$ [accessed Oct 2019]

Schulte, P. (1998), 'The entrepreneurial university: a strategy for institutional development,' Higher Education in Europe, vol. 29, no. 2, pp. 187-193. https://doi.org/10.1080/0379772042000234811

Schumpeter, J. (1908), 'On the concept of social value,' Quarterly Journal of Economics, vol. 23, pp. 213-232. https://doi.org/10.2307/1882798

Shevchenko, L. S. (2014), 'Universities as subjects of intellectual enterprise,' Theory and practice of Jurisprudence, vol. 1, no. 5, pp. 1-11.

Sklyar V. \& Tverytnykova, E. (2012), 'The formation of a scientific electrotechnical school in Ukraine (late XIX - first half of the XX century),' in Russian-Ukrainian Relations in the History of Science and Technology, Moscow, pp. 377-392.

State Archives of Kharkiv Region, F 770, op 1, n 180, 215, 246, 259, 780.

State Archives of Kharkiv Region, F P-1682, op 1, n 516.

Tarrant, J. (1976), Drucker: The Man Who Invented the Corporate Society, New York: Cahners Books.

Tverytnykova, E. (2010), The Origin and Development of Scientific and Technical School of Professor P. P. Kopnyayev, Kharkiv: NTU “KhPI".

Tverytnykova, E. (2017), 'The innovative research of Ukrainian research scientists in the field of analysis, optimization and automation of energy system modes in the second half of the 20th century,' Acta Baltica Historiae et Philosophiae Scientiarum, vol. 5, no. 2, pp. 100-107. https://doi.org/ 10.11590/abhps.2017.2.04

Tverytnykova, O. E.; Posvyatenko, N. I. \& Melnik, T. V. (2015), Essays on the History of the Development of Applied Technical Sciences in Ukraine. From the Experience of Kharkiv Polytechnic Institute, Kharkiv: Kharkiv Polytechnic Institute.

Maryna Gutnyk is an associate professor at the Department of Ukrainian Studies, Culturology and History of Science, National Technical University "Kharkiv Polytechnic Institute". She obtained her PhD degree in 2010. Her scientific interests include the history of higher technical school, the history of metallurgy and materials science.

Elena Tverytnykova is a professor at the Department of Information and Measuring Technologies and Systems, National Technical University "Kharkiv Polytechnic Institute". She received her doctoral degree in 2018. She worked at the Faculty as Deputy Dean on educational work; she is a member of the editorial board of the scientific collection of the history and philosophy of science and technology. She has authored several study guides and 
monographs. Her scientific interests include the history of higher technical school, the history of technical sciences and of electrical engineering.

Volodymyr Sklyar is head of the Department of Ukrainian Studies, Culturology and History of Science at the National Technical University "Kharkiv Polytechnic Institute". He received his doctoral degree in 2010. He has calculated the ethnic composition of the population of Ukraine. His scientific interests include the history of higher technical school, the history of famine in Ukraine. 